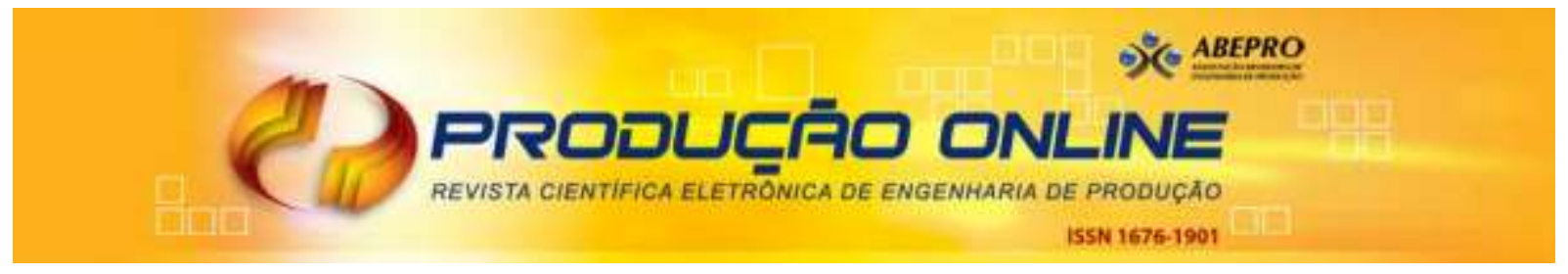

\title{
SERVITIZATION: ORGANIZATIONAL IMPLICATIONS AND ACQUISITION OF COMPETENCIES
}

\section{SERVITIZAÇÃO: IMPLICAÇÕES ORGANIZACIONAIS E AQUISIÇÃO DE COMPETÊNCIAS}

\author{
Silas Costa Ferreira Junior* E-mail: silascf@usp.br \\ Márcia Terra da Silva*E-mail: mtdsilva@usp.br \\ *Universidade de São Paulo (USP), São Paulo, SP
}

\begin{abstract}
Servitization is a strategic move in which firms - usually manufacturers in high value-added industriesexpand their offerings by bundling core products with additional services. This article aims to study the transition toward servitization from an organizational perspective, because the required organizational changes are among the main difficulties to overcome. The Star Model of organizational design was employed to describe and explain how such changes, in terms of strategy, structure, processes, people and rewards, were carried out in the textbook publishing industry. It is a particularly interesting sector, which has increasingly offered services and digital content, bundled with the printed textbook. A multi-case research was conducted in three textbook publishers in Brazil, focusing on their relationship with a key customer: the private primary and secondary schools. Data collected from the publishers' reports as well as interviews in the publishers and in the schools they serve, were analyzed and compiled in descriptive insights. Evidence suggest the adaptation of the publishers' capabilities and processes included changes in mindset to better understand the customer's needs; the acquisition of new competencies, usually by hiring former school employees with experience and interpersonal skills; and stronger integration between services (commercial) and product development (editorial) teams. The insights herein provided may encourage managers to evaluate and revise their current or future transition toward servitization.
\end{abstract}

Keywords: Servitization. Service Operations. Organization Design. Organizational Competencies.

Resumo: Servitização é um movimento estratégico no qual empresas - usualmente indústrias de alto valor agregado - expandem suas ofertas ao adicionar serviços aos produtos existentes. Este artigo busca estudar a transição à servitização sob uma perspectiva organizacional, pois as mudanças organizacionais requeridas estão entre as principais dificuldades a superar. O Modelo Estrela de design organizacional foi empregado para descrever e explicar como tais mudanças, em termos de estratégia, estrutura, processos, pessoas e recompensas, ocorreram na indústria de livros didáticos. Esse é um setor particularmente interessante, pois tem crescentemente oferecido serviços e conteúdo digital, ligados ao livro didático impresso. Uma pesquisa empírica de multi-casos foi realizada em três editoras no Brasil, focalizando em seu relacionamento com um cliente-chave: escolas privadas de ensino primário e secundário. Dados coletados de relatórios das editoras bem como de entrevistas nessas editoras e na sua clientela de escolas, foram analisados e então compilados em insights descritivos. Evidências sugerem que a adaptação das capacidades e processos das editoras incluíram mudanças de mentalidade, para melhor compreender as necessidades dos clientes; a aquisição de novas competências, usualmente pela contratação de ex-funcionários de escolas, experientes e com habilidades interpessoais; e maior integração entre equipes de serviços (comercial) e desenvolvimento de produtos (editorial). Os insights aqui oferecidos podem encorajar gestores a avaliar e revisar sua atual ou futura transição à servitização.

Palavra-chave: Servitização. Operações de Serviços. Projeto Organizacional. Competências Organizacionais. 


\section{INTRODUCTION}

Servitization and integrated solutions have attracted growing attention from academics and practitioners. This deliberate, strategic move can be regarded as a business model innovation driven by the following factors (MATHIEU, 2001): 1) the growing importance of the customer, customer loyalty and value-in-use principles; 2 ) higher profitability of certain services compared to related tangible products; and 3) competitive advantage and barriers to entry can be built by bundling core products with related services, which are offered to customers as a "solution" that is harder for competitors to imitate.

Despite the arguments for the servitization, its success is not guaranteed. Firms in some industries have difficulties in providing services, or do not believe in the profit potential of services, or would rather not risk the transition. Some researchers and business authors prescribe methods for a "safe journey", but the shift from the traditional production and sale of goods to integrated packages of goods and services is not failure-proof, requiring thus more empirical evidence (BAINES et al., 2009). Therefore, the main objective of this article is to empirically study the servitization process from an organizational perspective, as Neely (2007) proposes, by providing some empirical findings and insights regarding this sometimes difficult transition.

Becoming a servitized firm does not occur immediately; changes in a firm's capabilities and processes are required. Capabilities in production-once considered sufficient to give manufacturing firms a competitive edge — now must give way to other organizational capabilities related to interaction with customers and design of "solutions". For Ostrom et al. (2010), this includes developing and maintaining a new and pervasive service culture characterized by i) developing a service-oriented mindset, even in product-focused organizations; ii) creating a learning service organization that is able to harness both employee and customer knowledge; and iii) recruiting, training, and rewarding employees for sustained service.

Although Neu and Brown (2008) notice that servitization is applied and studied more frequently in high value-added industries, like the aerospace, telecommunications, information technology, and capital goods, servitization appears to be viable for any product or market, after the due adaptation (GEBAUER et al., 2012). Thus, empirical research will focus on a relevant sector that has been through such process: the textbook publishing industry. This average valueadded sector is considered a privileged field for servitization studies, due to the changes it has experienced worldwide, with the advent of digital technologies as well as the growing competition and falling prices, which have forced publishers to resort to services as another source of revenue. The plain printed textbook - which is the core tangible product, used in classrooms to connect teacher/school and student, due to its learning content- is giving way to wider relationships between publishers (manufacturers/suppliers) and schools (customers), with increasing supply of learning content and provision of related services. It has thus indicated that textbook publishers have "slid" toward more service, in the product-service continuum (OLIVA AND KALLENBERG, 2003).

In Brazil particularly, since the early 2000's, long-established local textbook publishers have witnessed the entry of competitors as well as regulatory changes concerning the textbook's quality standards (format and content). This dynamic context has forced Brazilian publishers to 
reformulate-or create for the first time-their competitive strategies, rethink their business vision and mission and invest in innovation. This all led to changes to the organizational design and managerial practices that have enabled the bundling of services with the textbooks.

\subsection{Research Problem and Objectives}

Neely (2007) offers a framework filled with opportunities for studying servitization and Product-Service Systems (PSS), with potential contributions to theory and practice. Studies on organizational issues usually focus on the innovation of capabilities and processes that enable a firm to design, build and deliver product-service solutions. The research problem is: How can "traditional" manufacturing firms make the transition to servitized organisations?, as proposed by Neely (2007) and Ostrom et al. (2010). Moreover, it will be investigated how these manufacturers design and build effective systems to deliver services that coexist with the systems that still produce the core products.

In addition to studying the servitization process from the manufacturer's perspective, this research is important because it also presents a complementary view, from the customer's perspective. That is, schools have been seeking to: 1) simplify textbook procurement, by selecting an "educational solution" that bundles the textbook with closely related services - training workshops that show schoolteachers how to utilize the textbook in class -, offered by a single publisher; and 2) outsource development activities regarding their teachers (technical skills) and support staff (managerial skills). Such customers' activities are usually the basis for new business opportunities in services (SAWHNEY et al., 2004). In fact, as it will be discussed, the services provided to schools by the servitized publishers tend to be the drivers for their organizational changes.

The objective of this research is then to understand how Brazilian textbook publishers have implemented the necessary organizational changes to become servitized. Specifically, it aims to describe and explain those changes and how they were implemented. The specific objectives for this research include the following:

$>$ To identify the transformation process with a frame of reference that consists of three phases: the need for change, the need for new competencies, and planning for the acquisition of new competencies;

$>$ To identify and explain the difficulties in the transformation from the industrial/taylorist logic to a new service logic, and the inherent difficulties in the transition to servitization as a new business model;

$>$ To describe and explain the changes in the relationships between the organizational elements that enable servitization: strategy, structure, processes, rewards, and people; and,

$>$ To describe the role and importance of people in the new organizational design.

This article is organized as follows: 2 - Literature Review; 3 - Methodological aspects; 4 Fieldwork and Results; 5 - Conclusions. 


\section{LITERATURE REVIEW}

Theoretical support for this research stems from the following key concepts: (i) the definitions and origins of servitization can explain the objectives of the firm with respect to this transformation; (ii) service relationship and service logic (ZARIFIAN, 2001a; VARGO AND LUSCH, 2004), which advocate for the need to consider customers' vision, needs, and activities to be effective; (iii) servitization and its organizational implications, including service competence and the new organizational model, which is formulated as an alternative to classic production models to support new production capabilities.

\subsection{Servitization and Integrated Solutions: Concepts, Features and Organizational Implications}

For Schmenner (2009), servitization has antecedents that go back as far as 150 years in the United States. Supply chains, as they are now known, have always been a mix of manufacturing and service activities; however, before approximately 1850, these activities were accomplished by different and distinct economic actors. Thus, Schmenner (2009) affirms that innovations in the supply chains of companies in the latter half of the nineteenth century led to the servitization innovations of today: at that point, service began to be bundled with goods and controlled by the same company. This step toward the customer, which is endorsed by Wise and Baumgartner (1999), pre-supposes that the manufacturer has some level of significant control over the downstream elements of its chain.

The term "servitization" was created by Vandermerwe and Rada (1988) to specifically capture the innovative business model in which firms previously known strictly as manufacturers, start to bundle services, support, self-service and knowledge together with their existing core product offerings, in order to add value to customers. In the present paper, the definition by Ren and Gregory (2007) will be adopted because it refers to the organizational issue: "Servitization is a change process wherein manufacturing companies embrace service orientation and/or develop more and better services, with the aim to satisfy customer's needs, achieve competitive advantages and enhance firm performance". In addition, the manufacturer gains control over the downstream operations of its value chain. A good example is the TotalCare Solution offered by Rolls-Royce Aerospace (NEELY, 2007). The firm no longer sells aircraft engines; instead, airlines buy "hours of flight" the engines deliver, while Rolls-Royce still owns the engines and keeps them ready for use and makes profit of it. Other example is the tech company IBM, which sells servers and then offers numerous services related to their operation and maintenance.

Similarly, a PSS is an integrated product-service offering that delivers value-in-use (BAINES et al., 2009; ARIENTE et al., 2014). Drucker (1973) noted that what is bought and considered valuable by customers is never a product but rather its utility-what a product does for the customer. In this sense, customers seek particular outcomes, and they engage in activities to achieve them. Firms that offer PSS redefine their markets in terms of customer activities and outcomes rather than product analogs because they acknowledge the utility of the referred product. 
In addition, the transition is undertaken in stages, each with related challenges (OLIVA AND KALLENBERG, 2003). Neu and Brown (2008) argue that manufacturers that succeed in this transition will exhibit two fundamentals from organizational theory. First, the internal alignment, which is the notion that each element of the organization must be designed to support rather than conflict with the others. The elements of the organizational design can be classified into five categories: strategy, structure, processes, rewards, and people (GALBRAITH, 2001). Second, the contingent design, which affirms that organizational performance depends on the degree to which the set of internal elements is designed to "fit" conditions in the external environment, such as market demands and regulations.

In summary, to undertake a successful servitization process, manufacturing firms require new principles; organizational structures and processes for production; human resource management systems (rewards, hiring and training); and support operations (BRAX, 2005). These principles, structures, and processes will likely be different from those associated with traditional manufacturing.

\subsection{New Principles: Service Relationship and Service Logic}

For successful servitization, the manufacturer needs behavioral principles that are consistent with service delivery (OLIVA AND KALLENBERG, 2003; GEBAUER and FRIEDLI, 2005; OSTROM et al., 2010). The behavioral principles are described as a service culture that encompasses a mindset driven by the customer (OSTROM et al., 2010) and by the service relationship (ZARIFIAN, 2001a).

The service relationship is not about the services sector itself but rather about the intensity of the relationships and interactions between suppliers and purchasers, who cooperate to obtain useful effects from the products and/or services (SALERNO, 2001). In this sense, the definition of service by Zarifian (2001a) seems particularly appropriate: "service is the transformation in the customer's conditions of activity". As a consequence, the service relationship is emphasized.

\subsection{The Customer-Activity Chain: Mapping the Opportunities in Services}

Complementary to Zarifian's view, Sawhney et al. (2004) developed the customer-activity chain (CAC), in order to identify systematically opportunities in new services that are derived from either core products or other previously existing services. They argue that in a world of "commoditized" products, many organizations have turned their attention to services to maintain growth in revenues even when their traditional core product markets decline. The CAC framework was devised to capture the type (how?) and focus (where?) of growth through services.

Sawhney et al. (2004) affirm that customers search for specific outcomes, and they engage in activities to achieve them. By mapping the CAC and relating it to a service-opportunity matrix, managers can systematically search for new opportunities with respect to services, with the following four resulting possibilities in the matrix:

- Temporal expansion: services that add new activities to a primary activity chain;

- Spatial expansion: services that add new activities to an adjacent chain; 
- Temporal reconfiguration: services that change the structure and control of activities within a primary chain; and

- Spatial reconfiguration: services that change the structure and control of activities within an adjacent chain.

Sawhney et al. (2004) also emphasize that, despite great possibilities, migrating to services might also be difficult and risky. The typical risks include market risk (will customers purchase the new services?), financial risk (is it possible to increase profitable revenues?), and capabilities risk (can the organization run the new services?). Fischer et al. (2010) also approach these issues by discussing the dynamic capabilities of sensing service opportunities; seizing service opportunities; and enhancing, combining, protecting, and reconfiguring the firm's assets to enable the provision of services.

\subsection{The New Organizational Design: Transition from Product-Centric to Customer-Centric}

The concept of organization has been discussed for almost a century by many authors and under a variety of approaches. The definitions currently available attempt to emphasize its complex and systemic nature, whereby its components contribute to the functioning of the whole. One framework has been demonstrated to be useful for understanding and designing organizations: the Star Model (GALBRAITH, 2001), which consists of five design policies (categories) that are controllable by managers and can influence employee behavior. Additionally, the model emphasizes that organizational design means more than mere structure.

For Galbraith (2001), policies are tools that managers must handle to effectively shape their organizations' decisions and behaviors. Policies form a sequence of steps consisting of the following: first, the definition of the company's strategy (what it does, where it wants to go); second, the company's structure (specialization, distribution of power, departmentalization, and shape); third, the company's processes (information flows); fourth, the company's reward system (influence on people's behavior); and fifth, the company's human resources policies (hiring and training). In sum, one of the best lessons from the Star Model is that each policy must be consistently aligned with the others.

Galbraith $(2002,2005)$ also studies the transition of organizational models, by focusing on customers and their need for solutions (the customer-centric approach) in contrast to a simple sale of goods (the product-centric approach). The transition begins by enabling the organization to understand who its customers are and to interact with them under this new vision. As with $\mathrm{Neu}$ and Brown (2008), Galbraith (2005) states that organizations that focus on meeting their customers' needs will experience growth in their customer portfolio and in customer loyalty, in addition to improving their financial performance. He adds that, not surprisingly, many will find the path to becoming customer-centric difficult because the product-centric mindset is still deeply entrenched in the culture of many manufacturers. Some of the differences between product-centric and customer-centric organizations are listed in Table 1. 
Table 1 - Change of focus and its effects on design policies.

\begin{tabular}{|c|c|c|c|}
\hline Design Policy & Features & Product-Centric Company & Customer-Centric Company \\
\hline \multirow{7}{*}{ Strategy } & Goal & Best product for customer & Best solution for customer \\
\hline & Main offering & Specific products & $\begin{array}{l}\text { Personalized packages of service, support, } \\
\text { education, consulting }\end{array}$ \\
\hline & Mental process & $\begin{array}{l}\text { Divergent thinking: How many possible uses } \\
\text { of this product? }\end{array}$ & $\begin{array}{l}\text { Convergent thinking: What combination of } \\
\text { products is best for this customer? }\end{array}$ \\
\hline & Value creation route & $\begin{array}{l}\text { Cutting-edge products, useful features, new } \\
\text { applications }\end{array}$ & Customizing for best total solution \\
\hline & Priority-setting basis & Portfolio of products & Portfolio of customers-customer profitability \\
\hline & Sales bias & On the side of the seller in a transaction & On the side of the buyer in a transaction \\
\hline & Most important customer & Most advanced customer & Most profitable, loyal customer \\
\hline Structure & Organizational concept & $\begin{array}{l}\text { Product profit center, product reviews, product } \\
\text { teams }\end{array}$ & $\begin{array}{l}\text { Customer segments, customer teams, } \\
\text { customer P\&Ls }\end{array}$ \\
\hline \multirow[b]{2}{*}{ Process } & Most important process & New product development & Customer relationship management \\
\hline & Measures & $\begin{array}{l}\text { - Number of new products } \\
\text { - Percentage of revenue from products less } \\
\text { than two years old } \\
\text { - Market share }\end{array}$ & $\begin{array}{l}\text { - Customer share of most valuable customers } \\
\text { - Customer satisfaction } \\
\text { - Lifetime value of a customer } \\
\text { - Customer retention }\end{array}$ \\
\hline Rewards & Bonus based on: & Business unit performance & Company performance \\
\hline \multirow[b]{2}{*}{ People } & Culture & $\begin{array}{l}\text { New product culture: open to new ideas, } \\
\text { experimentation }\end{array}$ & $\begin{array}{l}\text { Relationship management culture: searching } \\
\text { for more customer needs to satisfy }\end{array}$ \\
\hline & Approach to personnel & $\begin{array}{l}\text { Power to people who develop products } \\
\text { - Highest reward is working on next most } \\
\text { challenging product } \\
\text { - Manage creative people through challenges } \\
\text { with a deadline }\end{array}$ & $\begin{array}{l}\text { Power to people with in-depth knowledge of } \\
\text { customer's business } \\
\text { - Highest rewards to relationship managers } \\
\text { who help the customer's business }\end{array}$ \\
\hline
\end{tabular}

Source: adapted from Galbraith (2005)

\subsubsection{Service Competence: Individual Expression of the New Organizational Design}

Closely related to the categories of rewards and people in Galbraith's Star Model, Zarifian (2001b) affirms that realizing what is at stake in the transition in organization models is possible only with the emergence of competence logic, which consists of not only having knowledge but also applying it effectively, particularly when facing a problem (event). Consequently, this values the employee, recognizing his increased importance in the new work and organizational model.

Zarifian (2001b) then draws the link between customer-focused work and competencenow within this alternate organizational model-by showing that competence does not take the worker's formal qualifications for granted. On the contrary, it represents full recognition of the value of qualification in the context of a modern production system. In service operations, value tends to be delivered through skilled workers who have good customer interface and communication capabilities (BAINES et al., 2009). In particular, in situations that involve substantial customer contact, the workforce has a substantial portion of the service production and thus must have the competence to interact with customers. Several authors emphasize that the servitization process relies mainly on organizational changes related to people (BRAX, 2005; GEBAUER and FRIEDLI, 2005).

The work to be accomplished becomes an extension of the personal competence that an individual mobilizes when facing a situation, such as when he or she is called on to solve a problem. The work consists of interacting with the customer to build an interpretation of the results 
desired by the customer and then to create a solution. This serves as a good example of service competence in action in a customer-centric organization, which makes servitization possible.

\section{METHODOLOGICAL ASPECTS}

The empirical part was devised to describe and explain the transition toward servitization by applying the Star Model (GALBRAITH, 2001) and to allow the compilation of descriptive insights. Multiple case research was chosen, for the phenomenon relies largely on contextual analyses and qualitative data. Multiple cases, while limited to a manageable number, provide richer data for increased generalizability (BARRATT et al., 2011). The unit of analysis is the publisher as a whole, because the research problem focuses on the organizational implications of servitization; its departments, processes and personnel must therefore be investigated.

Data collection concentrated on the Star Model's organizational policies. In each publisher, secondary data from official websites and company reports were triangulated with primary data from three interviews, each in the following departments: new products (editorial), sales/marketing, and educational services. Next, it was triangulated again with primary data from two interviews in each school: one manager and one teacher. Within-case analyses were complemented with crosscase analysis (BARRATT et al., 2011). The final report herein presented essentially contains the cross-case analysis, regarding the empirical findings and the descriptive insights.

\subsection{Research Universe and Cases Selected}

This study focuses on the textbook publishing industry, in Brazil specifically. It consists of 19 publishers, and their current and potential customers include more than 35 thousand private schools that have nearly 8 million students (15\% of the total), who purchased approximately 20 million textbooks in 2010. Public schools are outside of the research scope, because the relationships with their "owner"-the government-are subject to specific laws that permit book purchase through a public bidding process that does not include services. Publishers had sales of 1.1 billion dollars in 2010 (SNEL, 2011), including private and governmental purchases. Figure 1 depicts the relationships among the industry participants. The network consists of two sections: the flow of ideas and services, and the flow of the tangible core product (the textbooks). The publishers are the principal agents, because they participate in both sections and coordinate the network.

Each case is a set of one publisher and two private schools that use the publisher's textbooks. The theoretical sampling has the following criteria: each publisher had to be a successful firm in the industry and provide services bundled with their textbooks, which would be classified as "products with services as an 'add-on"' (BAINES et al., 2009). Additionally, in each case one customer school has to be large, and one has to be small or midsized. Consequently, three publishers and six schools were chosen for the fieldwork. Last but not least, the three publishers have a combined $52 \%$ market share. Consequently, despite the selections not having statistical purposes, they provide a good overview of the industry and a sense of generality. 
Figure 1 - Relationship network for the textbook publishing industry (private schools)

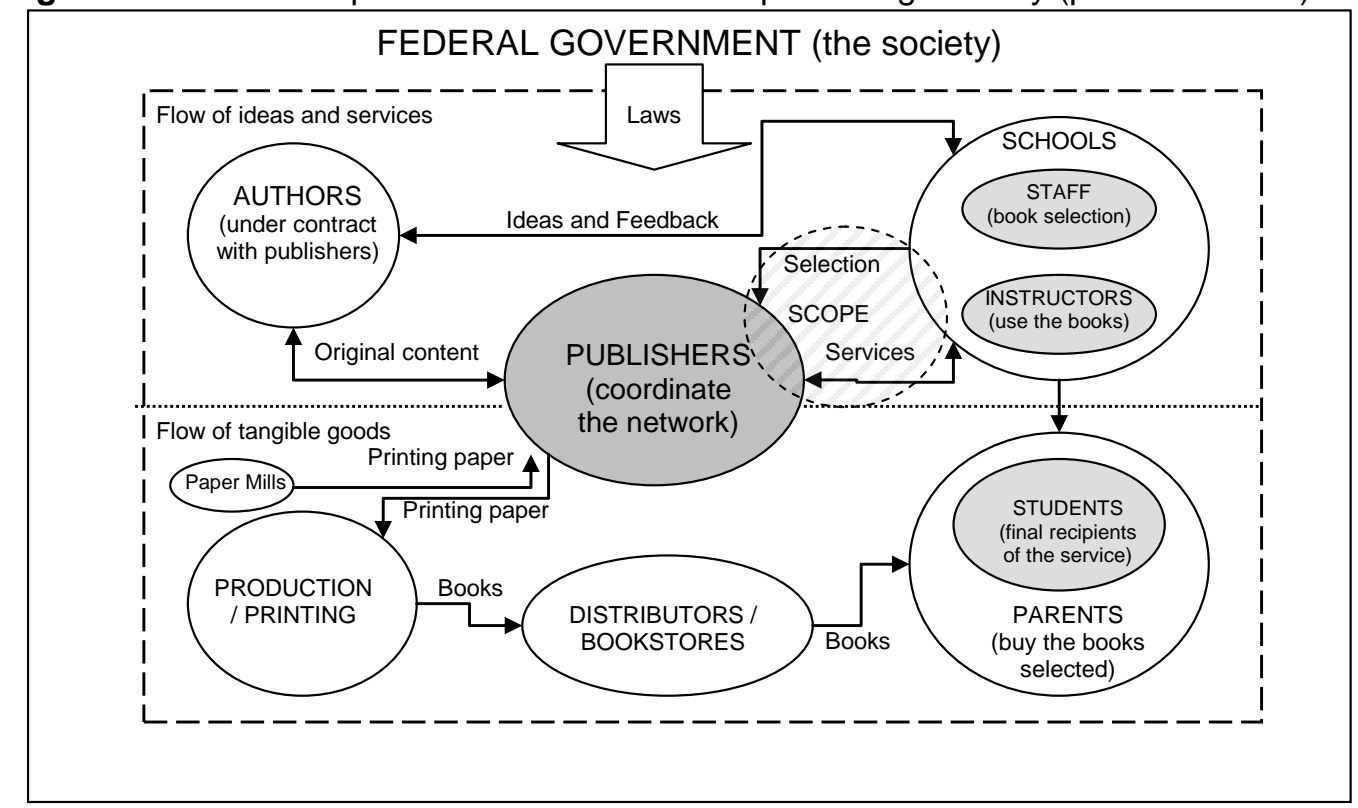

Source: elaborated by the authors

The first publishing firm, hereafter identified as Publisher1, was founded almost 50 years ago, by a pre-university preparatory program instructor, who used to create his own teaching materials, and then had the idea to develop more elaborate textbooks and sell them to primary schools. In the late 1990's a large Brazilian media group acquired it. The second firm, hereafter identified as Publisher2, is currently the market vice-leader, and was founded almost 45 years ago. In the early 2000's a large European media group acquired Publisher2 in order to enter the Brazilian market. The third and last firm, hereafter identified as Publisher3, was established approximately ten years ago as a full-fledged subsidiary of a midsize European textbook publisher, which decided to enter the Brazilian market by establishing a greenfield operation with its own traditional brand. Publisher3 is the smallest of the three firms, and was incorporated into the fieldwork due to its service culture imported from the headquarters in Europe and present in the Brazilian subsidiary since the very beginning. The case profiles are in Table 2.

Table 2 - Case profiles

\begin{tabular}{|c|c|c|c|c|}
\hline Firm & Item & Case1 & Case2 & Case3 \\
\hline \multirow{7}{*}{$\begin{array}{c}\text { Publisher } \\
\text { (Manufacturer) }\end{array}$} & Foundation (in Brazil) & Early 1960s & Late 1960s & Mid-2000's \\
\hline & Employees & 490 & 450 & 230 \\
\hline & \multirow{2}{*}{ Portfolio } & 400 textbooks & 700 textbooks & 240 textbooks \\
\hline & & 1200 literatures & 1430 literatures & 820 literatures \\
\hline & \multirow{3}{*}{ Interviews } & 1 - editorial & $1-$ editorial & 1 - editorial \\
\hline & & 1 - sales/marketing & 1 - sales/marketing & 1 - sales/marketing \\
\hline & & 1 - educational services & 1 - educational services & 1 - educational services \\
\hline \multirow{4}{*}{$\begin{array}{c}\text { School1 } \\
\text { (Customer) }\end{array}$} & Foundation & 90 years & 110 years & 60 years \\
\hline & Size & Large -3900 students & Large -2900 students & Large -1500 students \\
\hline & \multirow{2}{*}{ Interviews } & $1-$ manager & $1-$ manager & $1-$ manager \\
\hline & & 1 - teacher/instructor & 1 - teacher/instructor & 1 - teacher/instructor \\
\hline \multirow{3}{*}{$\begin{array}{c}\text { School2 } \\
\text { (Customer) }\end{array}$} & Foundation & 20 years & 10 years & 25 years \\
\hline & Size & Small -200 students & Small - 180 students & Midsize -500 students \\
\hline & Interviews & $\begin{array}{l}1 \text { - manager } \\
1-\text { teacher/instructor }\end{array}$ & $\begin{array}{l}1-\text { manager } \\
1-\text { teacher/instructor }\end{array}$ & $\begin{array}{l}1 \text { - manager } \\
1-\text { teacher/instructor }\end{array}$ \\
\hline
\end{tabular}

Source: elaborated by the authors 


\section{FIELDWORK AND RESULTS}

Figure 2 illustrates the publisher-school relationship and research scope. It was based on the industry network diagram (Figure 1) and describes both the sequence and activities in each tier. In addition, schools' educational activities and contact points with the publisher were examined to identify possible business opportunities in services. Although order management and physical production/distribution for the printed books (including relationships with paper mills, printing companies, distributors and bookstores) are important services, they are not relevant to the present research and thus will not be addressed. Author-publisher and school-student relationships are also excluded because the service relationship between them is beyond servitization's theoretical boundaries.

Figure 2 - The textbook chain and research scope

\begin{tabular}{|c|c|c|c|}
\hline Creator of original content & $\begin{array}{l}\text { Learning content: intangible } \\
\text {-order original learning content } \\
\text {-editorial process } \\
\text { Marketing/divulging: intangible } \\
\text {-catalogs/free-copies for schools } \\
\text { Services for schools: intangible } \\
\text {-training/development teachers } \\
\text {-educational project } \\
\text {-lectures with specialists } \\
\text {-pedagogical consulting } \\
\text {-school management }\end{array}$ & $\begin{array}{l}\text { Textbook selection } \\
\text {-editorial line evaluation } \\
\text {-textbook analysis/decision } \\
\text { Instructional Development } \\
\text {-training for the textbook } \\
\text {-class plans/additional pages for } \\
\text { special subjects } \\
\text {-classroom practice } \\
\text {-teacher assessment } \\
\text { Support staff development } \\
\text {-pedagogy/course design } \\
\text {-assignments/classrooms } \\
\text {-infrastructure }\end{array}$ & Final recipient of service \\
\hline
\end{tabular}

Source: elaborated by the authors

\subsection{The Schools: Activities and Needs Concerning Educational Solutions}

The fieldwork showed that publishers found a business opportunity in the private schools' need for solutions that value their teachers/instructors. Schools engage in activities to achieve a set of outcomes related to the satisfaction of their end consumers, i.e., students and ultimately their parents, who pay tuition and pay for the textbooks. Those outcomes consist of the development of two educational activities, teaching and information sharing, because both are designed to stimulate the student in the learning process. To achieve such stimulation, schools look for new pedagogical methods and technologies applied to education. However, they particularly want teachers to feel valued and to be recognized for their critical roles in students' learning processes. Such recognition and valuation are accomplished by investments in their teaching development such that they are able to supplement the student's performance by developing specific tasks-such as tests and homework-and by diagnosing and creating solutions for possible learning problems.

For the publishers, those opportunities in educational services fit into the ServiceOpportunity Matrix as Temporal Reconfiguration (Figure 3) for the following reasons:

1. They are located on the schools' primary activity chain; 
2. They are temporal, i.e., they occur within the time it takes for the school to complete the chain of primary activities that produce the outcomes related to its end costumers; and

3. They propose a simple reconfiguration of a temporal nature, i.e., new services (activities) are not created, but the publisher-school boundary is adjusted, and tasks previously carried out by the school are now undertaken by the publisher.

Figure 3 - Service-Opportunity Matrix for private schools

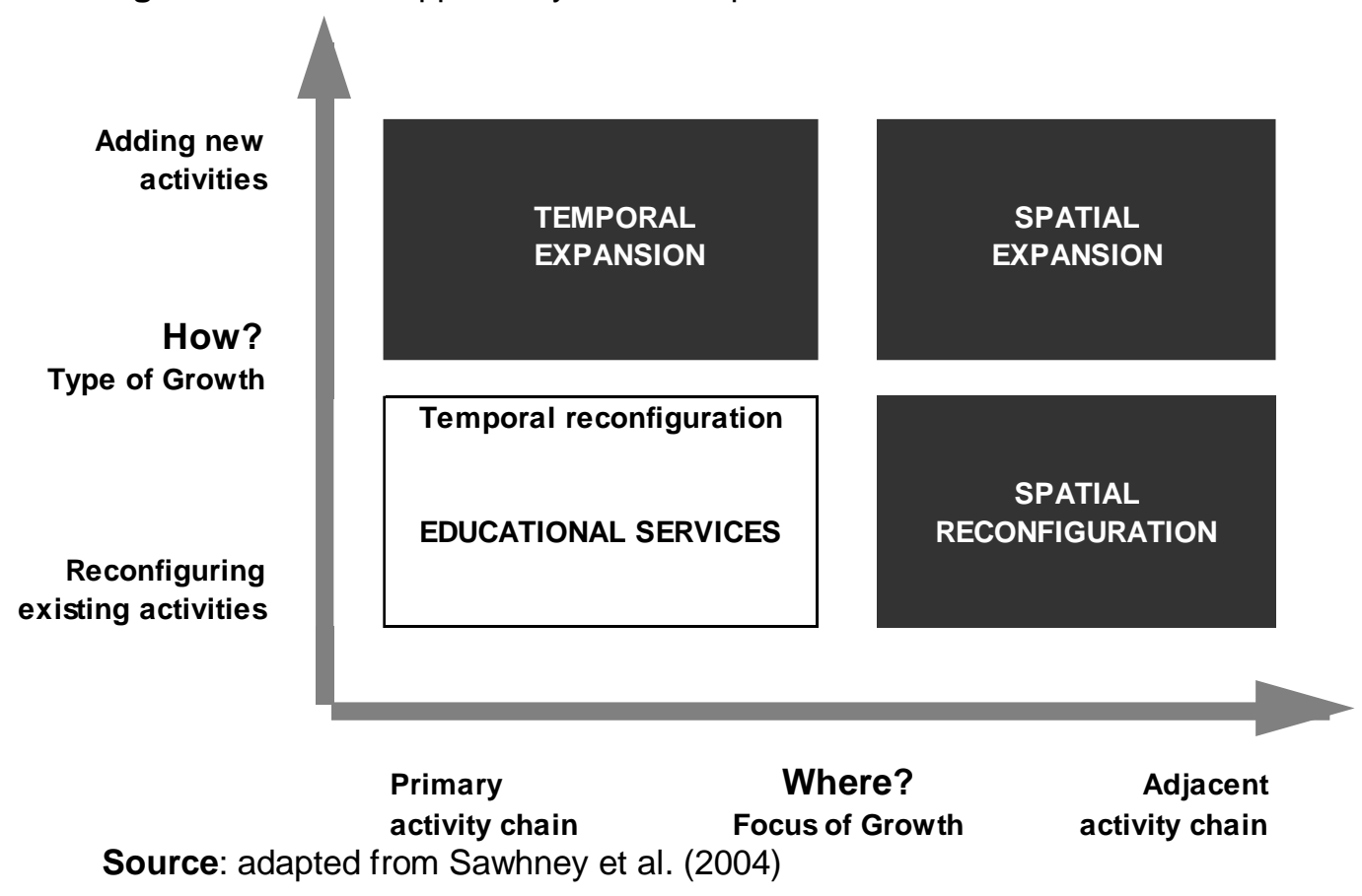

Based on the schools' perceptions of their own activities, the customer-activity chain (SAWHNEY et al., 2004) was devised as a means to better describe and explain the opportunities the publishers want to seize (Figure 4).

Publishers can deepen their relationships with schools by offering services that value teachers from a technical perspective, such as by providing training to use the textbook in class and offering classroom practice (see Figure 2). Reports such as that from McKinsey and Company (2007) show that a team of qualified teachers compensates certain deficiencies in the educational institution, such as those related to infrastructure and instructional material (textbooks included). Therefore, the actions that school managers take to qualify teachers by transforming their conditions of activity ultimately benefit them (MCKINSEY AND COMPANY, 2007) and likely increase their performance.

Additionally, schools also want improvements for support personnel who have non-teaching roles. These staff members act as teaching assistants and pedagogical coordinators and support the managers and particularly the teachers by giving them more time to focus on teaching issues. In this sense, schools seek to outsource staff training and development services. They cannot or do not want to provide the necessary training and development themselves because permanent training teams and consultants—with resulting higher expenses—would be required. 
Finally, schools also want a complete solution regarding instructional materials. When they select a textbook collection, they want it bundled with the appropriate training workshops that show instructors how to properly use the materials in class as well as the possibility to add complementary pages regarding special learning subjects and online materials, among other offerings. Textbooks are mass production goods that are selected exclusively by the schools, but actually, the consumers, i.e., the students' parents, do the purchase.

Figure 4 - Customer-activity chain for private schools

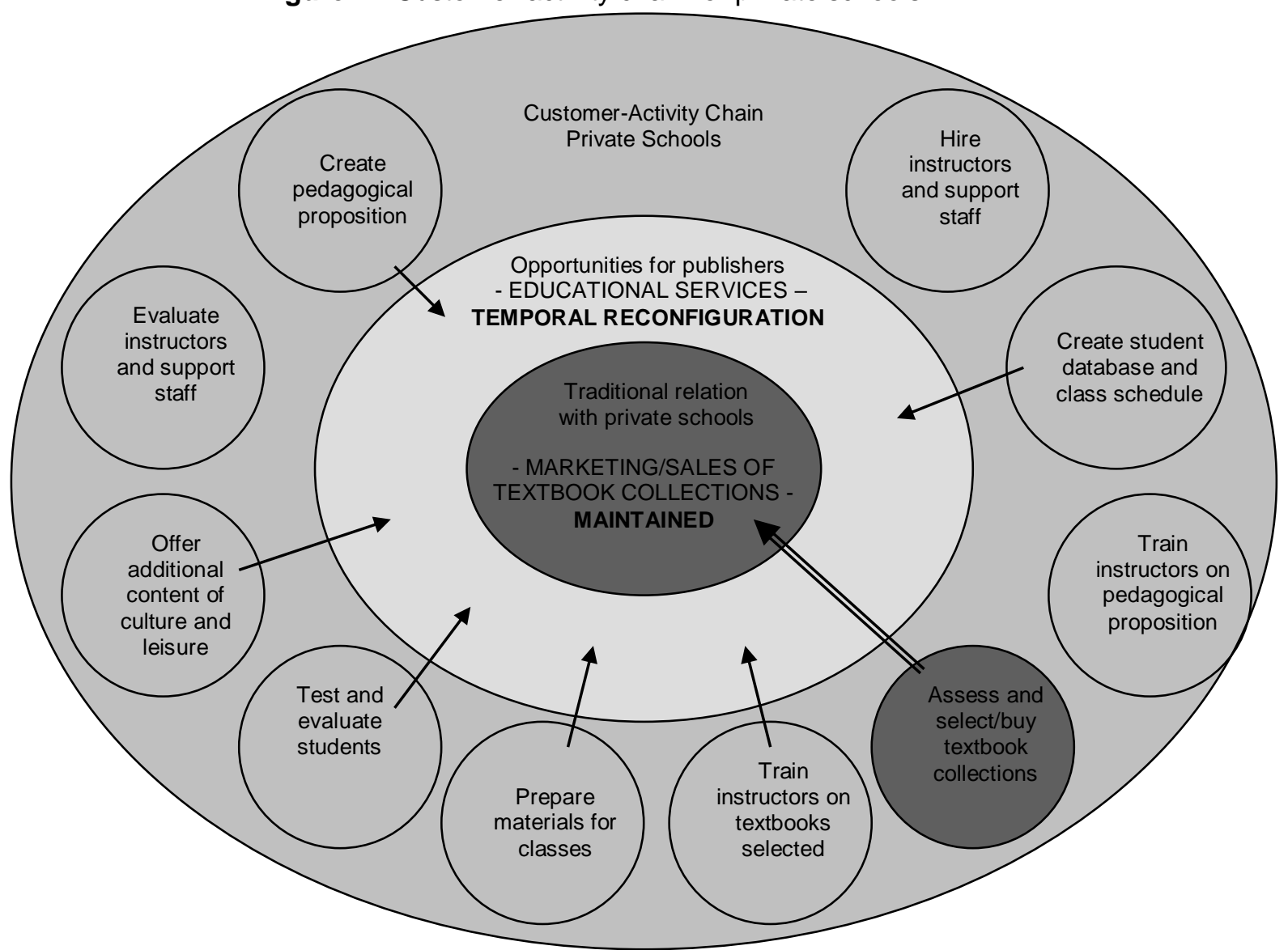

Source: adapted from Sawhney et al. (2004)

The aforementioned opportunities show the various possibilities for publishers to establish closer relationship with schools. Nevertheless, these opportunities will only come to effect with the organizational changes that enable them (SAWHNEY et al., 2004; GALABRAITHh, 2005; REN AND GREGORY, 2007).

\subsection{The Publishers - The Path to the Service Logic}

With respect to implementing the service logic, all of the publishers in the research achieved similar results: they brought the customers-the school and its instructors-into focus, understanding and interpreting their needs, such that a suitable solution might be created for them. 
Ferreira Junior et al. (2004), for example, argue that the textbook has extended beyond its materiality in the form of a "stack of printed paper" and has since been considered a medium for learning content transmission for students and, particularly, service provision for instructors. The idea of service, in the sense of transforming the school's teaching conditions, had different origins for each publisher. For example, Publisher1 and Publisher3 were both founded decades ago by schoolteachers; they were accustomed to seeing their own processes from the customers' perspectives. That idiosyncrasy became a latent part of their organizational cultures, and emerged when necessary.

In addition, the current transition from industrial logic to service logic was smooth, in part because those publishers found that a number of their own employees, particularly those in contact with customers, had previously worked in schools: they were teachers, pedagogical coordinators, and teaching specialists. Thus, when the new strategic directions were dispersed across the publishers studied (this will be discussed in the next subsection), part of the workforce was ready for the significant shift. However, part of the editorial staff in charge of new product development still had an industrial mindset with an isolated work style. A frequent opinion that arose from the interviews is exemplified as follows: "We know what we're doing: we create the book collections. Schools select them. Parents buy them for their kids. That's all."

That is, as in the past, they believed that schools would continue buying anything they produced. They were not prepared for the new reality, which requires leaving the "workstations" of the editorial process and beginning to listen to coworkers from the commercial area who collect feedback and suggestions from schools. The new service logic "opened eyes" in some departments, and clarified the possibility of increasing loyalty and revenues by providing services. The recognition that schools required not only the textbook but also a complete educational solution was a good opportunity for delivering increased value.

\subsection{The Publishers - Organizational Effects}

Responding to the external circumstances of growing competition, increased market demands, and new regulations, the three publishers formulated, almost simultaneously, a generic competitive strategy, all opting for differentiation. Publishers cannot realistically compete using a cost strategy because textbooks are knowledge-based products, thus the quality (of content and format) is emphasized instead of cost and final price. The need for organizational changes, beginning with vision and mission statements, quickly became apparent. For example, Publisher1 wrote a significant mission statement that leaves behind the role of strict producer of tangible goods in favor of learning content, and gives services a prominent role: "To be a qualified content provider for education, developing high-quality educational products for the Brazilian market, as well as a service provider to support educational institutions, teachers and students, using the best distribution channels." Please notice that the analogous product (textbook) is not even mentioned. Next, the publishers took the initiative to become solution providers, as they began to create services for schools. The first service was workshops to train teachers/instructors on the books that were selected. This transition took an average of five years. 
The organizational structure underwent some significant changes: the importance of technical systems was remarkably reduced. For example, Publisher2's production department was dismantled: assets (buildings, printing machines, etc.) were sold and employees were laid off, in order to concentrate on the core activities: the creation of learning content and relationships with customers. At the other two publishers, such department never existed: production had always been outsourced to third-party printing companies. The supply chain department now was in charge of placing production orders of books in accredited printing companies, according to the publisher's annual sales and inventory planning.

At the same time, the dimension of contact with the customer and product development increased in size and importance. New departments were created to provide services (see the list of services in Figure 2) and were typically subordinated to commercial or marketing directors. In the editorial departments, more staff was hired to respond to the schools' requests for tailor-made materials (the so-called "complementary pages" about special subjects) and new editions of existing collections.

The processes for exchanging information between the dimensions of customer contact and product development improved considerably, including the implementation of customer relationship management software. Another example was the improved editorial process (product development) at Publisher3: in order to reduce the time-to-market for new books (or new editions of the same book), the work flow was optimized with new procedures and software.

The design policy that changed the least was rewards. In general, rewards remained unchanged, maintaining long-existing official salary and profit-sharing policies, perhaps because the publishers are not aware of the options for linking the performance of a customer-school directly to an employee. Nevertheless, there was some progress, such as that in the commercial areas of Publisher1 and Publisher3: sales force bonuses were tied to school loyalty and revenues in services.

The rearrangements in the four design policies did impact the policy regarding the profile of employees. Those who had previously worked in schools were valued, and the hiring process (recruiting, interviewing, and selecting) reflected this change. Training and development policies also improved at all of the publishers studied, with a focus on interpersonal skills rather than technical skills. The service competence to meet new demands developed to address requests presented by schools, in particular. The competence to establish an effective relationship with the teacher personally_-by phone or even via the Internet-throughout the entire academic period is a challenge for all publishers. As discussed in the previous section, the "workstation culture" of the editors, which was marked by a high degree of isolation from the "outer world", was gradually replaced by a more "sociable" attitude, including the replacement of specific workers when necessary.

\section{DISCUSSION AND FINAL CONSIDERATIONS}

The research aimed at increasing knowledge on the servitization of manufacturing. This implies to describe and explain causalities and changes in the organizational elements, in order to understand the risks associated with such transition. Evidence suggest that, despite different 
starting points, the publishers have achieved similar results by adapting capabilities and processes to provide solutions that integrate the textbook with related services. Nevertheless, at present, it seems the case firms have not yet embraced bolder types of servitization, which might bring higher revenues, customer loyalty and/or competitive advantages (GALBRAITH, 2002; NEU AND BROWN, 2008). For example, despite the usefulness of the solutions offered, they cannot be considered a PSS per se because they do not deliver value-in-use related to the textbooks.

The servitization found in the cases (products with services as an add-on) is provided with a customer-centric strategy to deliver the desired outcomes and is caused by market drivers (increasing intensity in customer relationship and product differentiation). Therefore, such business model innovation is likely a direct consequence of the differentiation strategy put in place. In addition, the services that publishers provide can be categorized as consulting (educational project, school management, classroom practice, etc.) and outsourcing and operating (schools "outsource" the task of training teachers to use the "equipment", i.e., the textbook, to publishers), whereas for Gebauer et al. (2010), the service strategy related to servitization consists of customer support and outsourcing.

Organizational modifications were made in response to increased contact with customers, as usually happens according to Sawhney et al. (2004). The new structure for services was mixed with the existing commercial structure, with collaborative, synergic arrangements within departments. A completely new and isolated structure, such as a new firm, was not required.

Because one of the objectives of servitization is to increase revenues by offering services, one unexpected finding was that certain services are provided free of charge. For example, training instructors to use the textbooks, the most common service, requires no additional fee. In that case, the publishers concluded that the selection of the textbooks, and their consequent purchase, provides a sufficient payoff; furthermore, because of intense competition, such service is considered by schools an order-qualifier criterion. Unfortunately for the publishers, some services must be "for free" so that other, more expensive, offerings are "for fee" (NEU AND BROWN, 2008), even if they are not closely associated with the core product, such as school management consulting.

In fact, investigating how the publishers planned and conducted those organizational changes empirically showed the advantages and difficulties encountered in the transition to becoming a servitized firm. Some changes implemented were clear: the publishers became aware of the need to implement service logic prior to the provision of services, as suggested by Salerno (2001) and Oliva and Kallenberg (2003). Additionally, we determined that the analysis of a given case of servitization would be more effective if it began with an analysis of the firm's relationship networks and customer-activity chain. The customers' activities helped explain how the publishers identified and understood the schools' needs, and how those needs became business opportunities. Consequently, the organizational changes necessary for the publishers to seize such opportunities became clearer, as well.

One resulting change for managerial practice in the people dimension of the Star Model was the shift in recruitment and selection policies, to favor candidates who had previously worked for the customer in positions related to the primary activity chain. Therefore, the attention given to acquiring competencies_and particularly the service competence-to address the schools' needs 
demonstrates the desire for greater proximity with customers, as observed by Wise and Baumgartner (1999). As Vandermerwe and Rada (1989) said, people must identify with individual customers. Investments in infrastructure were also undertaken, in accordance with the observations of Mathieu (2001), Oliva and Kallenberg (2003) and Gebauer et al. (2010): departments for educational services were created and are now part of the publishers' sales/marketing divisions.

For the cases examined, the most important finding was the investment in people, for this organizational dimension is closely related to the adopted differentiation strategy and its underlying service logic (ZARIFIAN, 2001a). Particularly for those employees in contact with customers, education is about relationships more than other factors, even in the Internet era. Workers' profiles have changed, and they are now more proactive and disposed to teamwork, as suggested by Galbraith (2005). Additional obstacles must be overcome, such as integrating services teams (front end) and product development teams (back end), particularly when discussing feedback from customers. Solutions to that range from periodic meetings and adherence to communication protocols to visits by managers to customer schools for in-person meetings. Other difficulties include the increasing distribution of content-and provision of services—via the Internet, and poor communication with most customers, concerning the publisher's new value propositions.

In sum, servitization is a feasible business model innovation for medium-sized firms in nonhigh tech industries (GEBAUER et al., 2012), but the transition to servitization in the cases was not organized. On the contrary, the transition was based on gradual trial-and-error initiatives and took years to take effect, which on the other hand mitigated failure risks (BENEDETTINI et al., 2015). However, today two of the studied publishers lead the textbook publishing industry in Brazil. More active and prescriptive studies with a predetermined path for adapting to the changes a publisher will inevitably make might be an interesting direction for further research.

\section{REFERENCES}

ARIENTE NETO, R.; SILVA, S.; FORCELLINI, F.; GITIRANA, M.; CAUCHICK, M. Elementos integrantes de um sistema produto-serviço como potencial para alcançar um desenvolvimento sustentavel: bibliometria e análise de conteúdo. Produção online, v. 14, n. 3, 2014. http://dx.doi.org/10.14488/1676-

$\underline{1901 . v 14 i 3.1566}$

BARRATT, M; CHOI, T; LI, M. Qualitative case studies in operations management: trends, research outcomes, and future research implications. Journal of Operations Management, v. 29, n. 4, pp. 329342, 2011. http://dx.doi:10.1016/.j.jom.2010.06.002

BAINES, T.; LIGHTFOOT, H.; BENEDETTINI, O.; KAY, J. The servitization of manufacturing - A review of literature and reflection on future challenges. Journal of Manufacturing Technology Management, v. 20, n. 5, p. 547-567, 2009. http://dx.doi.org/10.1108/17410380910960984

BENEDETTINI, O.; NEELY, A; SWINK, M. Why do servitized firms fail? A risk-based explanation. International Journal of Operations \& Production Management, v. 35, n. 6, p. 946-979, 2015. http://dx.doi.org/10.1108/IJOPM-02-2014-0052 
Brax, S. A manufacturer becoming service provider - challenges and a paradox. Manufacturing Service Quality, v. 15, n. 2, p. 142-156, 2005. http://dx.doi.org/10.1108/09604520510585334

DRUCKER, P. Management: tasks, responsibilities and practices, Harper \& Row, New York, NY, 1973.

FERREIRA JUNIOR, S.; BERZAGHI, M.; SILVA, M. Livro é produto ou serviço? Análise de um caso de mudança na concepção do valor entregue ao cliente, In: ENCONTRO NACIONAL DE ENGENHARIA DE PRODUÇÃO - ENEGEP04. Anais... Florianópolis, p. 215-223, 2004.

FISCHER, T.; GEBAUER, H.; GREGORY, M.; REN, G.; FLEISCH. Exploitation or exploration in service business development? Insights from a dynamic capabilities perspective. Journal of Service

Management, v. 21, n. 5, p. 591-624, 2010. http://dx.doi.org/10.1108/09564231011079066

GALBRAITH, J. Designing organizations: an executive guide to strategy, structure, and process. JosseyBass, San Francisco, 2001.

GALBRAITH, J. Organizing to deliver solutions. Organizational Dynamics, v. 31, n. 2, p. 194-207, 2002. http://dx.doi.org/10.1016/S0090-2616(02)00101-8

GALBRAITH, J. Designing the customer-centric organization: A guide to strategy, structure and process, Wiley, New York, 2005.

GEBAUER, H.; FRIEDLI, T. Behavioral implications of the transition process from products to services. Journal of Business \& Industrial Marketing, v. 20, n. 2, p. 70-80, 2005.

http://dx.doi.org/10.1108/08858620510583669

GEBAUER, H.; FISCHER, T.; FLEISCH, E. Exploring the interrelationship among patterns of service strategy changes and organizational design elements. Journal of Service Marketing, v. 21, n.1, p. 103129, 2010. http://dx.doi.org/10.1108/09564231011025137

GEBAUER, H.; PAIOLA, M.; EDVARDSSON, B. A capability perspective on service business development in small and medium-sized suppliers. Scandinavian Journal of Management, v. 28, n. 4, p. 321-339, 2012. http://dx.doi.org/10.1016/j.scaman.2012.07.001

MATHIEU, V. Service strategies within the manufacturing sector: benefits, costs and partnership.

International Journal of Service Industry Management, v. 12, n. 5, p. 451-475, 2001.

http://dx.doi.org/10.1108/EUM0000000006093

MCKINSEY AND COMPANY (2007). How the world's best performing school systems come out on top. 2007. Disponível em: <http://mckinseyonsociety.com/how-the-worlds-best-performing-schools-come-outon-top/>. Acesso em: 12 dez. 2011.

NEELY, A. The servitization of manufacturing: an analysis of global trends. In: 14th EurOMA proceedings, Ankara, Turkey, pp. 186-196, 2007. 
NEU, W.; BROWN, S. Manufacturers forming successful complex business services: designing organization to fit the market. International Journal of Service Industry Management, v. 19, n. 2, p. 232251, 2008. http://dx.doi.org/10.1108/09564230810869757

OLIVA, R.; KALLENBERG, R. Managing transition from products to services. International Journal of Service Industry Management, v. 14, n. 2, p. 1-10, 2003. http://dx.doi.org/10.1108/09564230310474138

OSTROM, A., BITNER, M., BROWN, S., BURKHARD, K., GOUL, M., SMITH-DANIELS, V., DEMIRKAN, H. AND RABINOVICH, E. Moving forward and making a difference: research priorities for the science of service. Journal of Service Research, v. 13, n. 1, p. 4-36, 2010. http://dx.doi:10.1177/1094670509357611

REN, G. AND GREGORY, M. Servitization in manufacturing companies: a conceptualization, critical review, and research agenda, In: Proceedings of the 16th Annual Frontiers in Service Conference, San Francisco, 2007.

SALERNO, M. A. seu serviço: interrogações sobre o conceito, os modelos de produção e o trabalho em atividades de serviços. In Relação de Serviço. Produção e avaliação, Ed SENAC, São Paulo, 2001.

SAWHNEY, M.; BALASUBRAMANIAN, S.; Krishnan, V. Creating growth with services. Sloan Management Review, v. 45, Winter, p. 34-43, 2004.

SCHMENNER, R. Manufacturing, service, and their integration: some history and theory. International Journal of Operations and Production Management, v. 29, n. 5, p. 431-443, 2009.

http://dx.doi.org/10.1108/01443570910953577

SINDICATO NACIONAL DOS EDITORES DE LIVROS (SNEL). Anuário e análises mercadológicas, Rio de Janeiro, 2009.

Vandermerwe, S.; Rada, J. Servitization of business: adding value by adding services. European Management Journal, v. 6, n. 4, p. 314-324, 1988. http://dx.doi.org/10.1016/0263-2373(88)90033-3

VANDERMERWE, S.; RADA, J. European manufacturers shape up for services. Journal of Business Strategy, v. 10, n. 6, p. 42-46, 1989. http://dx.doi.org/10.1108/eb039335

VARGO, S.; LUSCH, R. Evolving to a New Dominant Logic for Marketing. Journal of Marketing, v. 68 January, p. 1-17, 2004. http://dx.doi.org/10.1509/jmkg.68.1.1.24036

VELTZ, P.; ZARIFIAN, P. Vers de nouveaux modeles d'organisation?. Revue du sociologie du travail, v.35, n. 1, p. 3-25, 1993.

WISE, R.; BAUMGARTNER, P. Go downstream: the new profit imperative in manufacturing. Harvard Business Review, v.77, n. 5, p. 133-141, 1999.

ZARIFIAN, P. Valor, organização e competência na produção de serviço - esboço de um modelo de produção de serviço, In: Relação de Serviço: produção e avaliação. São Paulo: SENAC, p. 95-149, 2001a. 
ZARIFIAN, P. Objetivo competência: por uma nova lógica. Atlas, São Paulo, 2001b.

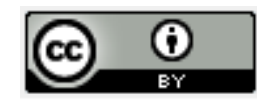

Artigo recebido em 24/02/2015 e aceito para publicação em 01/11/2016

DOI: http://dx.doi.org/ 10.14488/1676-1901.v16i4.1998 